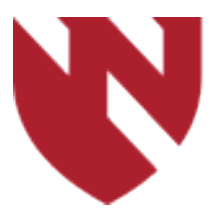

\title{
Neurolytic Celiac Plexus Blockade in Patients with Upper Intraabdominal Malignancies: An Evidence-Based Narrative Review
}

Kevin Wong

Desert Orthopedic Center

Apollo A. Stack

University of Nebraska Medical Center

Madhuri Are

University of Nebraska Medical Center

Tell us how you used this information in this short survey.

Follow this and additional works at: https://digitalcommons.unmc.edu/gmerj

Part of the Higher Education Commons, and the Medicine and Health Sciences Commons

\section{Recommended Citation}

Wong, K., Stack, A. A., , Are, M. Neurolytic Celiac Plexus Blockade in Patients with Upper Intraabdominal Malignancies: An Evidence-Based Narrative Review. Graduate Medical Education Research Journal. 2020 Dec 09; 2(2).

https://digitalcommons.unmc.edu/gmerj/vol2/iss2/5

This Literature Review (Systematic or Meta-Analysis) is brought to you for free and open access by DigitalCommons@UNMC. It has been accepted for inclusion in Graduate Medical Education Research Journal by an authorized editor of DigitalCommons@UNMC. For more information, please contact digitalcommons@unmc.edu. 


\title{
Neurolytic Celiac Plexus Blockade in Patients with Upper Intraabdominal Malignancies: An Evidence-Based Narrative Review
}

\author{
Abstract \\ Background: Cancer-related abdominal pain is a common symptom associated with upper intra- \\ abdominal carcinoma, especially in patients with advanced disease and it has posed a significant \\ therapeutic challenge to medical practitioners. Typically, cancer pain can be managed by following the \\ World Health Organization 3-step analgesic ladder. However, analgesic use of opioids, the mainstay \\ treatment for moderate-to-severe cancer-related pain, may be ineffective in a subset of cancer patients. \\ Escalation of dosage may be limited by opioid-induced side effects. The aim of this study was to review \\ the literature addressing the effect of neurolytic celiac plexus block (NCPB) on the palliation of pain \\ emanating from advanced upper intra-abdominal malignancies. \\ Methods: Electronic databases including Medline/PubMed, EMBASE, and Cochrane Library were \\ searched. Only studies with a high level of evidence were reviewed. These included prospective \\ randomized control studies, systematic reviews and meta-analyses. Further, references from included \\ articles were carefully reviewed for additional relevant trials. \\ Results: A total of 13 prospective randomized trials, 5 systematic reviews and meta-analyses, and one \\ Cochrane review article were found to meet eligibility criteria. \\ Conclusion: Neurolysis of the celiac/splanchnic plexus is an effective and safe therapeutic modality that \\ should be considered early for palliation of cancer-related pain in advanced upper intra-abdominal \\ malignancies. This is especially true for patients with intolerable opioid-induced adverse events and \\ painful symptoms resistant to oral analgesics.

\section{Keywords} \\ Cancer, abdominal pain, evidence-based medicine, autonomic nerve block, analgesia, neurolysis, opioids, \\ sympathetic nervous system

\section{Creative Commons License}

\section{c) (i) (9)}

This work is licensed under a Creative Commons Attribution-Noncommercial-No Derivative Works 4.0 License. 


\title{
Neurolytic Celiac Plexus Blockade in Patients With Upper Intraabdominal Malignancies: An Evidence-Based Narrative Review
}

\author{
Kevin Wong ${ }^{1}$, Apollo A. Stack², Madhuri Are
}

${ }^{1}$ Desert Orthopedic Center, Eisenhower Medical Center, Rancho Mirage, CA

${ }^{2}$ University of Nebraska Medical Center, Department of Anesthesiology, Omaha, NE

${ }^{3}$ University of Nebraska Medical Center, Department of Anesthesiology, Division of Pain Medicine, Omaha, NE

\begin{abstract}
Background: Cancer-related abdominal pain is a common symptom associated with intraabdominal malignancies, especially in patients with advanced disease and it has posed a significant therapeutic challenge to medical practitioners. Typically, cancer pain can be managed by following the World Health Organization three-step analgesic ladder. However, the use of opioids, the mainstay treatment for moderate-to-severe cancerrelated pain, may be ineffective in a subset of cancer patients. Escalation of dosage may be limited by opioid-induced side effects. The aim of our study was to review the literature addressing the effect of neurolytic celiac plexus block (NCPB) on the palliation of pain emanating from advanced upper intraabdominal malignancies.
\end{abstract}

Methods: Electronic databases including Medline/PubMed, EMBASE, and Cochrane Library were searched. Only studies with a high level of evidence were reviewed. These included prospective randomized control studies, systematic reviews and meta-analyses. Furthermore, references from included articles were carefully reviewed for additional relevant trials.

Results: A total of 13 prospective randomized trials, five systematic reviews and metaanalyses, and one Cochrane review article were found to meet eligibility criteria.

Conclusion: Neurolysis of the celiac/ splanchnic plexus is an effective and safe therapeutic modality that should be considered early for palliation of cancer-related pain in advanced upper intra-abdominal malignancies. This is especially true for patients with intolerable opioid-induced adverse events and painful symptoms resistant to oral analgesics.

\section{Introduction}

Despite recent advances in diagnostic and therapeutic modalities, cancer remains as the second leading cause of death in the U.S. ${ }^{1}$ Pain is a relatively common cause of cancerrelated disability and the leading contributor to poor quality of life (QoL). ${ }^{2}$ About 25 to $40 \%$ of cancer patients reported dying in agony secondary to moderate-to-severe pain in their final three days. ${ }^{3,4}$ With increased life expectancy in cancer patients it is important to prevent needless suffering through prompt and effective pain control, as a significant number of cancer victims bear a poor prognosis, especially those with advance-staged disease. ${ }^{5}$ Thus, in 70 to $80 \%$ of patients with advanced disease, and up to $90 \%$ of those with bone metastases, ablative procedures including neurolysis of the celiac/splanchnic plexus should be sought to improve analgesic outcomes. $^{6}$

\section{Pathophysiology of Cancer-Related Pain} Cancer-related pain can be classified as nociceptive, neuropathic, or mixed. ${ }^{7}$ Nociceptive pain can be further classified as somatic or visceral. ${ }^{7}$ Somatic pain is described as a squeezing or sharp sensation that can be localized as a focal point of tenderness. ${ }^{7}$ Stimulation of peripheral sensory neurons, or nociceptors, by noxious stimuli from tumor invasion or compression of adjacent somatic structures leads to somatic pain. ${ }^{8,9}$ On the contrary, visceral pain presents in a poorly localized, diffuse pattern that is accompanied by a deep pressure-like sensation. ${ }^{7,10}$ It can be triggered by smooth muscle spasm, distension of hollow viscus or organ capsule, chemical irritation, stretching or twisting of the mesentery as well as ischemic injury of visceral organs. ${ }^{9}$ Regardless of whether the source is visceral or somatic, most patients respond favorably to traditional analgesics.

Effective control of cancer-related neuropathic pain remains a challenge as the outcome of standard treatment is relatively unpredictable. ${ }^{11}$ Neuropathic pain may be perceived as burning, tingling, shooting and/ or lancinating forms of sensation. ${ }^{7}$ Further, difficulties associated with the management of neuropathic pain may be multifaceted involving peripheral and central sensitization, neuroplasticity and modulation of the nociceptive somatosensory pathway within the central nervous system. ${ }^{12}$

Regardless, the mechanism of cancer-related pain can be attributed to a multitude of mechanical, inflammatory, neuropathic, and ischemic factors due to tumor infiltration of neural structures, direct compression of adjacent tissues, peripheral neuropathy from chemotherapy, plexopathy and fibrosis from radiation therapy, and chronic postsurgical pain..$^{9,13}$ Treatment of cancer-related pain can be achieved through multiple modalities including pharmacological, chemoradiotherapy, palliative surgeries and interventional pain therapies.

\section{Pharmacological Management of Upper Intraabdominal Malignancies}

Traditionally, the mainstay of cancer-related analgesia is opioid-based. However, there is increasingly more evidence supporting a multimodal therapeutic approach. ${ }^{11}$ In general, 70 to $90 \%$ of cancer-related pain can be managed by following the three-step analgesic ladder developed by the World Health Organization in $1986 .{ }^{14}$ However, 10 to $20 \%$ of advanced cancer patients, especially those with neuropathic pain and bone metastases, remain refractory to standard therapies. ${ }^{3,10,15}$ Despite a multimodal pharmacological approach, patients with upper intraabdominal malignancies frequently experience excruciating pain during the course of their illnesses and psychological distress at the end of life. ${ }^{12}$ Neurolytic celiac plexus block (NCPB) has been proposed as an alternative to ameliorating pain in patients with advanced upper intraabdominal malignancies.

\section{Relationship between Cancer-Related Pain and Survival \\ Pain frequently creates considerable distress in cancer patients. The prevalence of pain in cancer patients was alarmingly high, with $53 \%$ of cancer patients at all disease stages reporting it. ${ }^{14}$ Given the tremendous advances in cancer therapy, which have resulted in better life-expectancy and increased long-term survival, the number of individuals suffering from cancer pain is bound to increase substantially.}

It has long been speculated that uncontrolled pain may pose a negative impact on the survival of cancer patients. Cancer-related pain is postulated to promote tumor growth and metastases through a complex interplay of cellular pathways and consequently shorten survival. ${ }^{16,17}$ Putative mechanisms include attenuation of immune response via inhibitory effect on natural killer (NK) cells, 
stimulation of mitogen-activated protein kinase (MAPK) to facilitate tumor growth, and chronic activation of mu-opioid receptors (MOP-R) from increased level of endorphins or frequent use of opioids. ${ }^{16,17}$ Elevated levels of endorphins and exogenous use of opioids are thought to be the predominant triggers that facilitate these mechanisms, leading to reprogramming of tumor cells and thereby promoting tumorigenesis. ${ }^{16}$

Of note, systemic use of opioids has become an integral part of providing high-quality palliative care for cancer patients. However, numerous in-vitro and in-vivo studies have demonstrated a dual effect on cancer survival associated with administering systemic opioids. ${ }^{18}$ Several mechanisms have been proposed, including tumor cell proliferation due to imbalance of pro- and anti-apoptotic enzymes, angiogenesis as a result of modulation of vascular endothelial growth factor (VEGF) signaling, metastasis due to changes in matrix metalloproteinases (MMP), as well as expression, activity level, and neurogenic inflammation due to changes in gene expression of inflammatory cytokines and receptors. ${ }^{18}$ Together, these studies have highlighted the diametrically opposed potentials of opioids in promoting or inhibiting tumor proliferation. Given this duality, it is not surprising that the association between opioid usage and survival in cancer patients remains unclear. In addition, the common nature of opioid-induced side effects and concerns related to tolerance, dependence, and aberrant drug-seeking behaviors have persuaded many practitioners to seek alternatives for effective palliation of cancer pain.

Interventional techniques have been advocated as safe and effective strategies for palliation of cancer-related pain without causing intolerable side effects. There is accumulating evidence implicating perineural invasion of tumor cells in the pathogenesis of tumor growth and migration. ${ }^{16}$ Recent evidence from a preclinical study in mouse models of pancreatic ductal adenocarcinoma demonstrated that early denervation of peripheral sensory fibers using capsaicin significantly delayed neoplastic growth and prolonged median survival by 3.3 months $(p=$ $0.001) .{ }^{19}$ Similar findings have been reported in other animal models including vagal nerve ablation in gastric cancers, sympathectomy in prostate cancer, and denervation of the dorsal cutaneous nerve in basal cell carcinoma. ${ }^{20,21,22}$ Taken together, these models support the notion that early surgical or chemical denervation such as NCPB may prevent neoplastic development, progression, and metastasis, resulting in improved pain relief and prolonging survival.

\section{Neuroanatomy of the Celiac Plexus}

The celiac plexus is an extensively interconnected network of neural structures within the sympathetic nervous system. It is formed by paired celiac ganglia and autonomic fibers. ${ }^{23}$ The celiac ganglia supply nociceptive and sympathetic efferent outputs via thoracic splanchnic nerves to the upper abdominal viscera including pancreas, gallbladder, diaphragm, liver, spleen, distal esophagus, stomach, small bowel, ascending and proximal transverse colon, adrenal glands, kidneys, abdominal aorta and mesentery. ${ }^{24,25}$ Similarly, nociceptive inputs from visceral organs carried by afferent fibers will pass through the celiac ganglia, thoracic splanchnic nerves, and sympathetic ganglia to reach the spinal cord. Thoracic splanchnic nerve fibers branch off the sympathetic trunk and descend medially through the diaphragmatic crura along the paravertebral border to synapse with celiac ganglia. ${ }^{23}$ The paired celiac ganglia lie medial to the adrenal glands and anterior to the descending thoracoabdominal aorta bilaterally at T12 and L1 vertebral levels in the retroperitoneal space..$^{23,26}$ Despite considerable anatomical variability, the greater and lesser splanchnic nerves most frequently arise from $\mathrm{T} 5$ to $\mathrm{T} 9$ and $\mathrm{T} 9$ to T12 ganglia, respectively; while the least splanchnic nerves are formed by nerve roots arising from T11 to T12 ganglia. ${ }^{23}$

\section{Techniques of Celiac/Splanchnic Nerve Block} The percutaneous celiac/splanchnic nerve block has been ubiquitously performed for the management of both malignant and non-malignant pain involving the upper abdominal viscera. The classic approach to blocking these afferent nociceptive impulses is described as the posterior percutaneous retrocrural technique. ${ }^{27}$ Several modifications of this conventional approach have been described, which include transcrural, 28,29 transaortic,,$^{30}$ transdiscal,,${ }^{31}$ and anterior approach. ${ }^{32,33}$ The diaphragmatic crura serves as an important landmark for this nerve block. Chemical denervation of the celiac plexus can be achieved with either a transcrural or transaortic approach; while blockade of the splanchnic nerves can be accomplished with a retrocrural approach..$^{27,34}$

Traditionally, the nerve block was performed blindly using anatomical landmarks. Trimble et al. first reported successful relief of upper abdominal malignant pain via blockade of the celiac plexus in 1952. ${ }^{35,36}$ The concept of fluoroscopy-guided celiac plexus block was introduced by Bonica et al. in $1954 .{ }^{37}$ Clinical application of other advanced imaging modalities, such as computed tomography (CT), endoscopic ultrasound (EUS), and videoscopic thoracoscopy, have also become increasingly common to improve needle accuracy, increase patient safety, reduce catastrophic complications and enhance block efficacy. Successful blockade of the celiac plexus has also been demonstrated via direct injection of neurolytic agent during surgical laparotomy. ${ }^{38,39,40,41}$

\section{Posterior Approach}

The patient is placed in prone position. A 20 - or 22-gauge, 12 to $15 \mathrm{~cm}$ needle is placed approximately $7.5 \mathrm{~cm}$ lateral to the midline and caudal to the 12 th rib on each side..$^{42,43}$

The needles are advanced at a 450 angle with a slight 15 o cephalad direction toward the coronal plane. Lateral redirection of the needle by gradual increments is required upon bony contact of the first lumbar vertebral body. Once the needle has walked off the vertebral body, the needle on the left side should be advanced 1.5 to $2 \mathrm{~cm}$ until aortic pulsation can be detected. The same is repeated on the right side with the needle advancing into the retrocrural space (Figure 1) ${ }^{44,45}$ Incomplete sympathetic blockade of the celiac plexus may occur with the classic retrocrural approach. Penetration of a neurolytic agent through the aortic hiatus in the diaphragm is mandatory, as demonstrated by Moore et al. in 1981, with needle placement posterior and cephalad to the diaphragmatic crura. ${ }^{46}$

The classic retrocrural approach was modified to a transcrural technique by Boas and Singler. ${ }^{28,29,47}$ There is no difference in terms of needle placement on the left side (Figure 2). However, the needle placed on the right side will be advanced slightly further, about 2 to $3 \mathrm{~cm}$, just enough to penetrate ventrally through the right diaphragmatic crura. Regardless of whether the approach is retrocrural or transcrural, the laterality of needle placement on each side prompted the search for modified techniques including the transdiscal and transaortic approaches (Figure $3 \mathrm{~A}$ and $\mathrm{B}$ ). Both techniques require only one needle projecting directly toward the central region of the celiac plexus, causing less patient discomfort and tissue injury. Contrast medium is used to confirm correct placement of needles and adequate spreading around the T12 and L1 vertebral bodies. A diagnostic block of local anesthetic with epinephrine should be performed prior to all sympathetic neurolysis, consistent with usual standards for regional nerve blocks.

Anterior Approach

A modification of the classical approach 
is the CT- or ultrasound-guided anterior approach (Figures. $4 \& 5$ ). The intervention is performed with the patient supine and needle is inserted perpendicular to the skin slightly left of midline around the epigastric region at $1.5 \mathrm{~cm}$ below xiphoid process. ${ }^{48}$ The needle is advanced into the precrural space immediately anterior to the abdominal aorta located between the origins of the celiac trunk and superior mesenteric artery. ${ }^{49}$ The possibility of tumor cell seeding in the needle track should always be considered in cancer patients following the trans-pancreatic approach. Proper needle placement can be confirmed by the spread of contrast within the anterolateral aspect of diaphragmatic crura. ${ }^{49}$ The purpose of this paper is to review the literature addressing the effect of neurolytic celiac plexus block (NCPB) on the palliation of pain emanating from advanced upper intraabdominal malignancies.

\section{Materials and Methods}

We conducted an electronic literature search in the following databases: Medline/ PubMed, EMBASE, and Cochrane Library without specific limitation on the year of publication. A search of the available literature was performed in November 2017, with the assistance of a librarian, using search terms that captured publications related to cancer pain, efficacy, survival, quality of life, celiac plexus, splanchnic nerve, nerve block, neurolysis, neurolytic, denervation, carcinoma, neoplasm, metastases, cancerrelated and tumor. The number of initial hits from these search terms was over 10,000 articles and was further narrowed down to only those that also included the terms celiac plexus and/or splanchnic nerve. The authors initially reviewed titles and abstracts to find the most pertinent studies before full texts were read to determine inclusion/exclusion. Only prospective randomized control trials, systematic reviews and meta-analyses were considered for review. All articles written in non-English language were excluded. A secondary search of the bibliographies and citations of all included articles was performed to ensure inclusion of all relevant articles.

\section{Results}

A total of six randomized controlled trials (RCTs), one prospective randomized uncontrolled trial, one prospective nonrandomized controlled trial, one Cochrane review, and five systematic reviews and/ or meta-analyses were eligible for review of the efficacy of NCPB. There were two

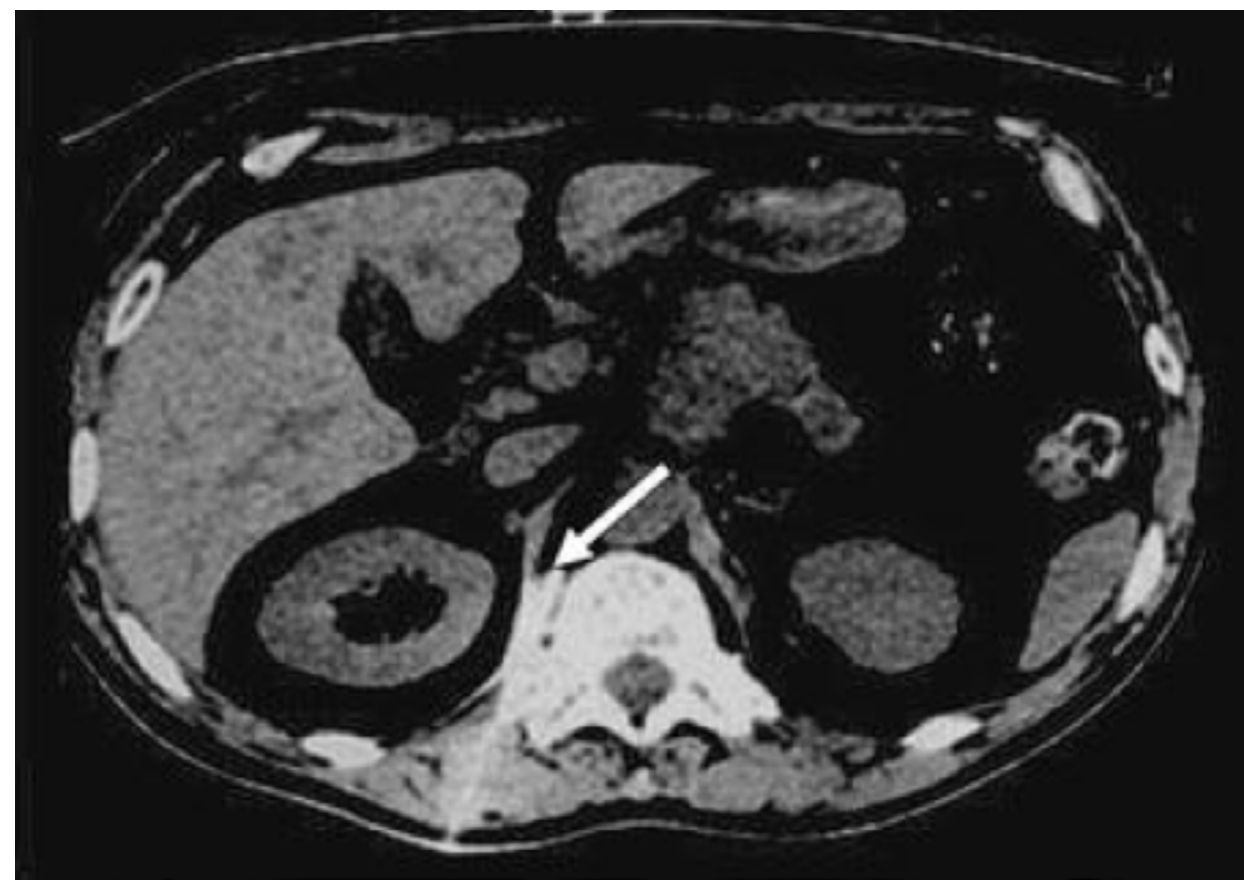

Figure 1. Computed tomography showing proper positioning of spinal needle in the right retrocrural space. [Reprinted by permission from the Rightslink service of CCC: Springer Nature, Abdominal Imaging. CT-guided percutaneous neurolytic celiac plexus block technique. Wang PJ, Shang MY, Qian Z et al. 2006.]

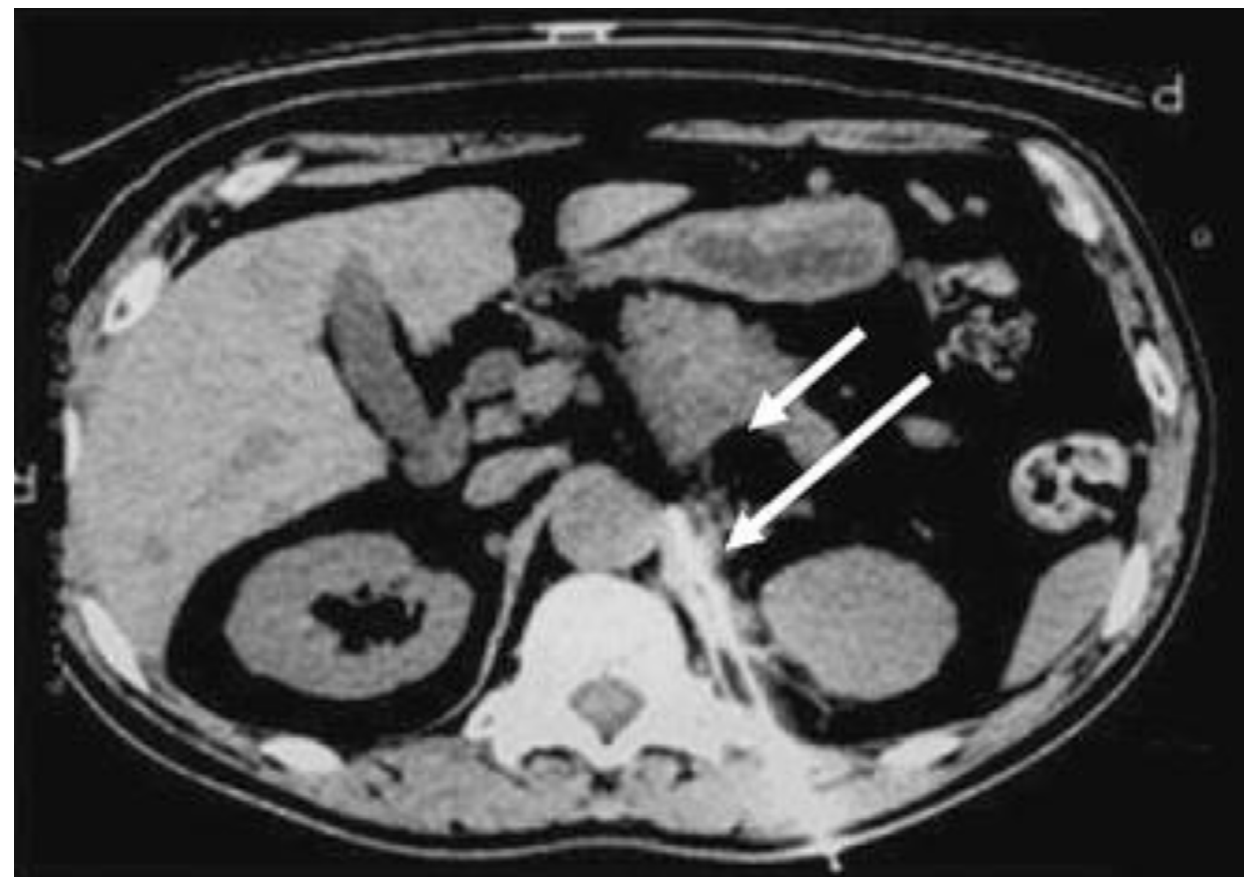

Figure 2. Computed tomography showing the transcrural technique with placement of spinal needle tip just pass the left diaphragmatic crura. [Reprinted by permission from the Rightslink service of CCC: Springer Nature, Abdominal Imaging. CT-guided percutaneous neurolytic celiac plexus block technique. Wang PJ, Shang MY, Qian Z et al. 2006.] 

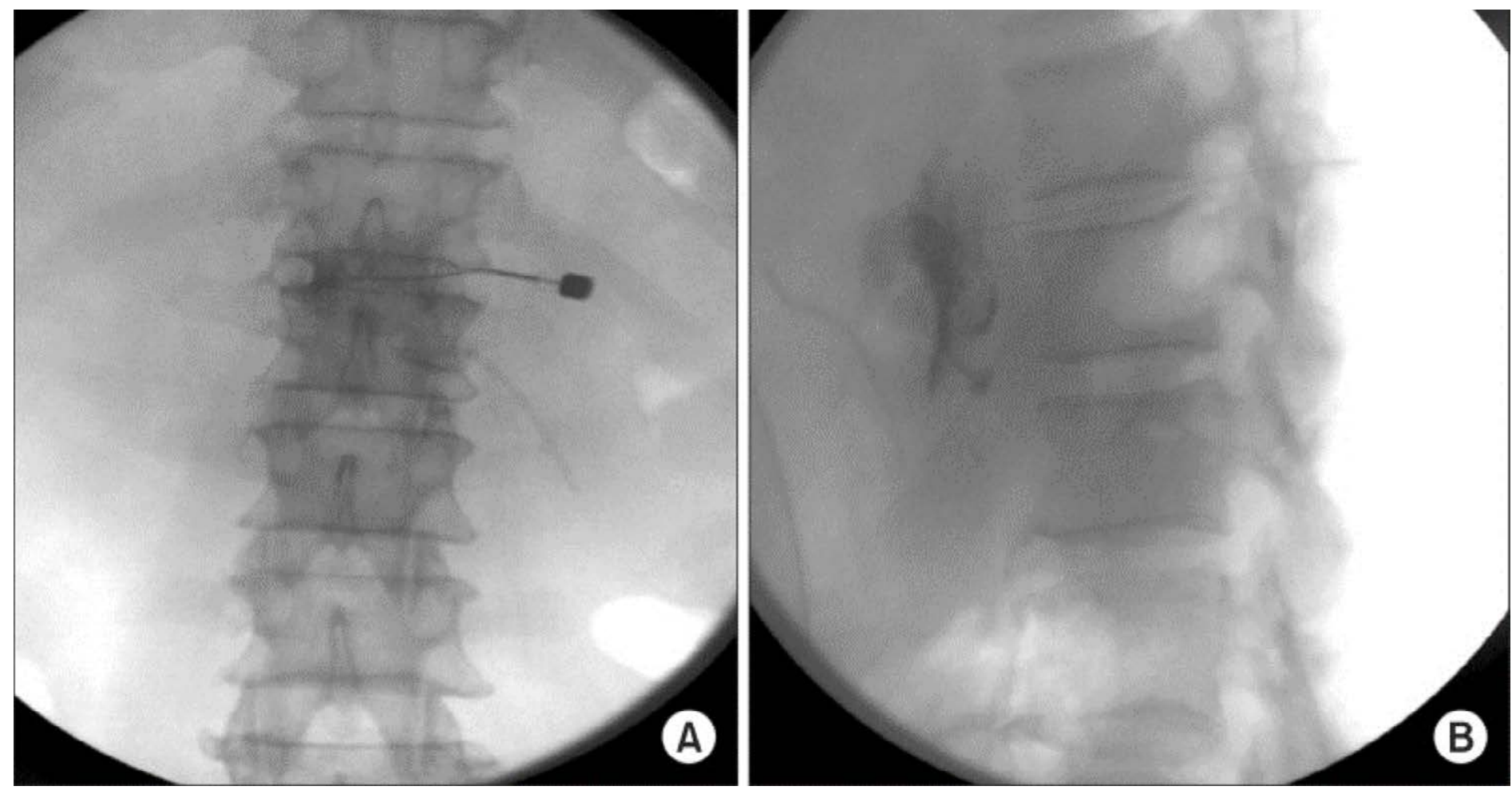

Figure 3. The A-P (A) and lateral $(B)$ views demonstrating contrast spread in the retrocrural space with the unilateral, single-needle transdiscal approach. [Computed tomography (CT) simulated fluoroscopy-guided transdiscal approach in transcrural celiac plexus block by Kong GY et al. Copyright 2013 by The Korean Pain Society. Reprinted by permission under the terms of Creative Common License CC BY-NC 3.0]
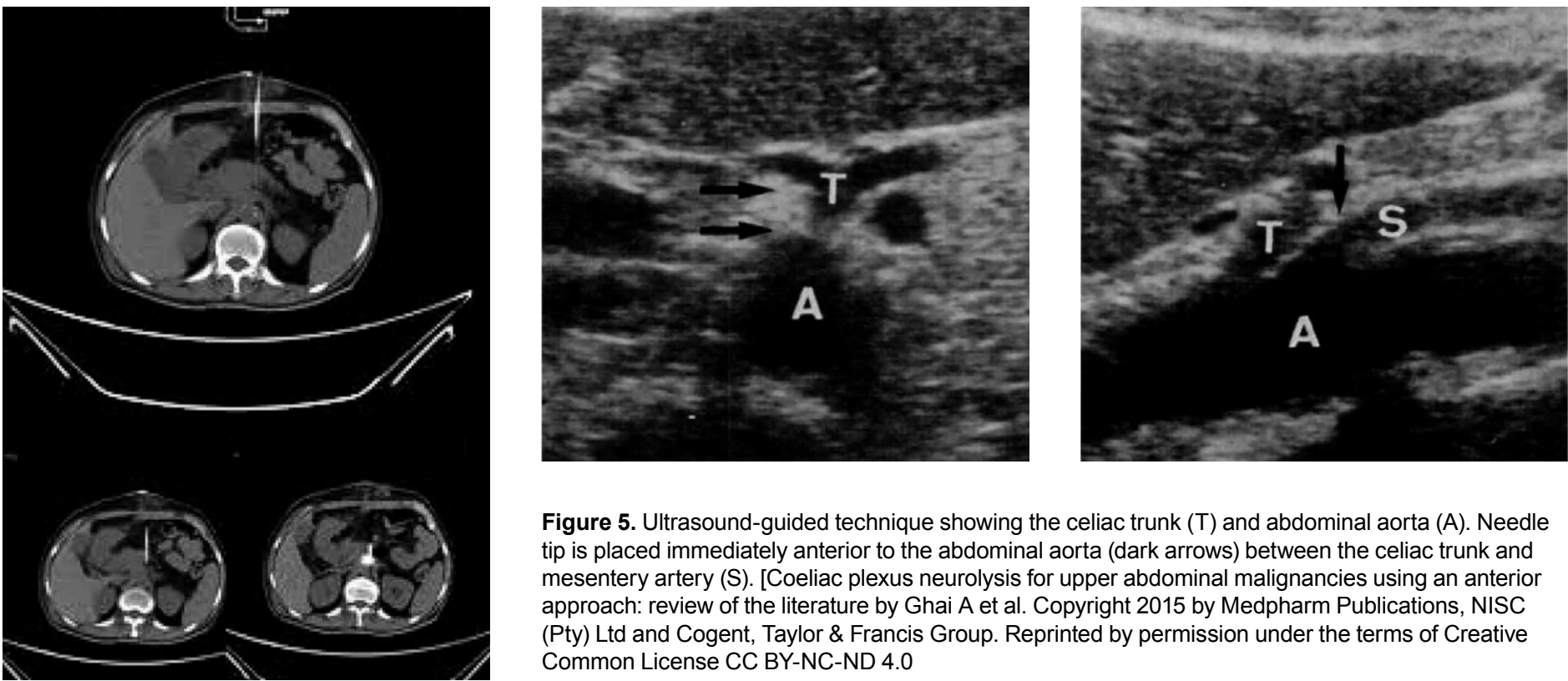

Figure 5. Ultrasound-guided technique showing the celiac trunk $(T)$ and abdominal aorta $(A)$. Needle tip is placed immediately anterior to the abdominal aorta (dark arrows) between the celiac trunk and mesentery artery (S). [Coeliac plexus neurolysis for upper abdominal malignancies using an anterior approach: review of the literature by Ghai A et al. Copyright 2015 by Medpharm Publications, NISC (Pty) Ltd and Cogent, Taylor \& Francis Group. Reprinted by permission under the terms of Creative Common License CC BY-NC-ND 4.0

Figure 4. Computed tomography demonstrating the transpancreatic approach with appropriate spread of contrast immediately anterior to the abdominal aorta along the celiac axis. [Coeliac plexus neurolysis for upper abdominal malignancies using an anterior approach: review of the literature by Ghai A et al. Copyright 2015 by Medpharm Publications, NISC (Pty) Ltd and Cogent, Taylor \& Francis Group. Reprinted by permission under the terms of Creative Common License CC BY-NC-ND 4.0] 
prospective randomized studies that compared the efficacy of celiac plexus block with splanchnic nerve block. There were four prospective studies related to the effect of NCPB on QoL and five prospective studies related to the effect of NCPB on survival (Table 1). One RCT was found that detailed different volumes of alcohol in celiac plexus block. There was only one retrospective study comparing the effectiveness of alcohol and phenol in NCPB.

\section{Discussion}

Efficacy of Celiac/Splanchnic Plexus Neurolysis Prospective Clinical Trials Neurolytic blockade of the celiac plexus was originally reported by Kappis in $1914 . .^{50}$ However, the first prospective randomized control study was not published until 1992. ${ }^{51}$ Ischia and associates evaluated 61 patients with unresectable pancreatic cancer who were randomized to undergo one of the 3 posterior percutaneous approaches to NCPB, namely, transaortic, classic retrocrural, and bilateral chemical splanchniectomy. They reported abolition of cancer-related celiac pain in $75 \%$ of patients immediately post-NCPB and up to $67 \%$ of patients at the time of death $(p<$ $0.01)$. Interestingly, they found that only 10 $24 \%$ of patients had complete pain relief from NCPB alone at the time of death, but up to $80-90 \%$ when combined with other therapies, suggesting the clinical significance of a multimodal analgesic approach. The authors concluded that there was no statistically significant difference in efficacy, morbidity, performance status, survival rate, and type of recurrent or residual pain among these three techniques.

A smaller RCT of 20 patients with advanced pancreatic cancer was performed to investigate the effectiveness of NCPB in alleviating severe cancer-related pain. ${ }^{52}$ This pilot study by Mercadante in 1993 compared the effectiveness of NCPB to traditional nonsteroidal anti-inflammatory drugs (NSAIDs) and opioid treatment on cancerrelated pain relief. Overall, both NCPB and systemic analgesic therapy (SAT) provided statistically significant reductions in visual analogue scale (VAS) pain scores and opioid dosage requirements at all seven weekly follow-up intervals up to the time of death. The authors concluded that NCPB may be more desirable than SAT because of less opioid-induced side effects.

The largest single center, double-blinded RCT by Lillemoe and colleagues provided highquality, level-one evidence. ${ }^{53}$ Among the 137 patients evaluated, chemical splanchniectomy with alcohol significantly reduced mean pain scores at 2, 4, and 6 months, and within two months of death, especially for those with significant preoperative pain $(p \leq 0.05)$. Time to rescue with NCPB was also substantially longer in the NCPB group compared to the SAT group (11.8 vs. four-months; $p \leq 0.05$ ). Despite improved mood and lower disability scores in patients receiving alcohol, there was no statistically significant difference between the alcohol and saline group. Adverse events were reportedly minor and self-limited. Their findings support the efficacy and safety of intraoperative alcohol splanchniectomy in advanced pancreatic cancer patients for attaining favorable outcomes, including significantly lower mean pain scores, lower analgesic consumption, longer duration of pain relief, and lower incidence of significant pain at death.

Kawamata et al. published a pilot RCT of 21 patients with pancreatic cancer in 1996, highlighting the effect of NCPB on healthrelated QoL. ${ }^{54}$ Consistent with the outcomes from previous studies, NCPB significantly reduced VAS pain score during first four weeks immediately after the procedure compared to SAT $(p<0.05)$. Morphine consumption was found to be substantially reduced from week four to seven after NCPB $(p<0.05)$.

In an RCT published in 1998, Polati et al. performed NCPB in 24 patients who had unresectable pancreatic cancer over a two-year period..$^{55}$ They found complete pain relief within $24-48$ hours after NCPB in $75 \%$ of patients compared to merely $17 \%$ in SAT $(p<0.05)$. There was also a significant reduction in diclofenac use, opioid consumption, and drug-related adverse events in patients with NCPB. Notably, the complete abolition of pain was achieved in only one patient with NCPB alone, but nine patients when combined with SAT. This finding was consistent with those reported by Ischia and associates, supporting the clinical importance of a multimodal analgesic therapy. Despite favorable outcomes in the reduction of VAS pain score and oral analgesic use within $24-$ 48 hours of treatment, the long-term results were not significantly different between the two groups.

Wong et al. conducted a prospective, doubleblinded RCT evaluating the effect of NCPB on pain relief and opioid consumption involving 100 patients with unresectable pancreatic cancer. ${ }^{56}$ Both NCPB and SAT substantially reduced pain intensity compared to baseline, with the NCPB group demonstrating a significantly greater pain reduction than the SAT group (53\% vs. $27 \%$, $p=0.005)$. Sustained analgesic benefits of NCPB lasted until the time of death. There was a gradual increase in opioid usage due to tumor progression. Contrary to previous studies, ${ }^{52,54,55}$ there was no significant difference in opioid consumption between NCPB and control $(p=0.93)$.

Jain et al. reported similar outcomes in 100 consecutive patients with advanced malignancies suffering from upper abdominal pain or backache..$^{57}$ These patients demonstrated superior analgesic benefits from NCPB compared to SAT, where the VAS pain score was significantly lower at 7 and 30 days after $\operatorname{NCPB}(p=0.03$ and $p=0.005$, respectively). Consistent with most studies, mean consumption of morphine was lowered by $50 \%$ at the 30 -day interval in the NCPB group ( $p=0.00$ ), with $31 \%$ of these patients requiring only non-opioid and other adjuncts for pain relief. The major weakness of this study was imposed by the limitation of a nonrandomized and non-blinded design.

The efficacy of CT-guided NCPB was assessed in a randomized control trial by Zhang et al. involving patients with unresectable pancreatic cancer. ${ }^{58}$ All 56 patients who received either CT-guided NCPB or SAT obtained significant reduction in VAS pain score at 1, 7, 14, 30, 60, and 90 days after treatment compared to baseline VAS pain score $(p<0.01)$. A significant difference in the reduction of VAS pain score between the two groups was found at only 1,7 , and 14 days after treatment $(p<0.01)$. Morphine requirement was also significantly lower in patients with NCPB at 7,14, 30, 60, and 90 days after treatment compared to patients with SAT $(p<0.01)$. The authors concluded that CT-guided NCPB with alcohol is effective for treatment of intractable pancreatic cancer pain.

Systematic Review and Meta-Analysis Eisenberg and colleagues conducted the first meta-analysis to assess the efficacy and safety of NCPB in patients with intraabdominal malignancies. ${ }^{59}$ This meta-analysis pooled all data published in 21 retrospective studies, one prospective study, and two RCTs from 1966 to 1993, which involved a total of 1145 patients with either pancreatic $(63 \%)$ or non-pancreatic (37\%) intraabdominal malignancies. The authors found that NCPB provided both shortand long-term analgesic efficacy in 89\% (95\% CI: 86.9-90.9) and 90.2\% (95\% CI: 77.9-96.3) of patients, respectively. Importantly, 6 of the 24 studies demonstrated either partial or complete pain relief in $73 \%$ and $92 \%$ of patients, respectively. The reasons underlying 
Table 1.

List of prospective studies evaluating the effect of neurolytic celiac/splanchnic plexus blockade on pain reduction, opioid consumption, quality of life, and/or survival in patients with advanced intraabdominal malignancies.

\begin{tabular}{|c|c|c|c|c|c|c|c|c|c|}
\hline $\begin{array}{l}\text { Ischia et al., } \\
\text { 1992. }\end{array}$ & $\begin{array}{l}\text { Prospective, } \\
\text { randomized } \\
\text { study }\end{array}$ & $\begin{array}{l}\text { Patients with } \\
\text { unresectable } \\
\text { pancreatic cancer } \\
\text { pain aged } 39-73\end{array}$ & 61 & $\begin{array}{l}\text { Transaortic celiac } \\
\text { plexus block vs. } \\
\text { classic retrocrural } \\
\text { nerve block vs. } \\
\text { bilateral chemical } \\
\text { splanchniectomy }\end{array}$ & $\begin{array}{l}\text { VAS pain } \\
\text { score, Arner } \\
\text { and Arner pain } \\
\text { classification, } \\
\text { performance } \\
\text { status, } \\
\text { survival, type } \\
\text { of recurrent or } \\
\text { residual pain }\end{array}$ & $\begin{array}{l}\text { Transaortic - } 30 \\
\text { ml of absolute } \\
\text { alcohol via each } \\
\text { needle; classic } \\
\text { retrocrural }-15 \mathrm{ml} \\
\text { of absolute alcohol } \\
\text { via each neeedle; } \\
\text { bilateral chemical } \\
\text { splanchniectomy } \\
-7 \mathrm{ml} \text { of absolute } \\
\text { alcohol via each } \\
\text { needle }\end{array}$ & $\begin{array}{l}\text { There was no statistically significant difference in } \\
\text { efficacy and morbidity among the three-posterior } \\
\text { percutaneous NCPB. Success rate was reported } \\
\text { to be } 70-80 \% \text { immediately after procedure and } \\
60-75 \% \text { at the time of death. }\end{array}$ & $\begin{array}{l}\text { Transient, minor complications } \\
\text { were self-limited, which } \\
\text { include diarrhea, dysesthesia, } \\
\text { reactive pleurisy, hiccoughing, } \\
\text { and hematuria. Orthostatic } \\
\text { hypotension was reported in all } \\
\text { three techniques but significantly } \\
\text { less likely with transaortic } \\
\text { approach. No operative mortality } \\
\text { was reported. }\end{array}$ & $\begin{array}{l}\text { NCPB is an appropriate } \\
\text { percutaneous technique for } \\
\text { pain relief in patients with } \\
\text { pancreatic cancer. }\end{array}$ \\
\hline $\begin{array}{l}\text { Mercadante } \\
\text { et al., } 1993^{52} \text {. }\end{array}$ & $\begin{array}{l}\text { Prospective, } \\
\text { randomized } \\
\text { study }\end{array}$ & $\begin{array}{l}\text { Pancreatic cancer } \\
\text { patients with one- } \\
\text { week treatment } \\
\text { of NSAID and } \\
\text { opioid analgesic } \\
\text { therapy }\end{array}$ & 20 & NCPB vs. SAT & $\begin{array}{l}\text { VAS pain } \\
\text { score, opioid } \\
\text { consumption }\end{array}$ & $\begin{array}{l}25 \mathrm{ml} \text { of } 75 \% \\
\text { alcohol bilaterally }\end{array}$ & $\begin{array}{l}\text { There was significant reduction of baseline } \\
\text { VAS score in both treatment groups by the } 8^{\text {th }} \\
\text { week or at the time of death. However, there } \\
\text { was no significant difference in VAS score } \\
\text { between the two treatment groups. Patients who } \\
\text { received celiac plexus block required less opioid } \\
\text { consumption for the following } 8 \text { weeks or up to } \\
\text { the time of death. }\end{array}$ & $\begin{array}{l}\text { There was one case of prolonged } \\
\text { diarrhea requiring octreotide, two } \\
\text { cases of orthostatic hypotension } \\
\text { lasting } 48 \text { hours requiring } \\
\text { vasopressors, and one case of } \\
\text { back pain at the needle entry site. }\end{array}$ & $\begin{array}{l}\text { NCPB is safe and reduces } \\
\text { opioid consumption for pain } \\
\text { control in pancreatic cancer } \\
\text { patients. }\end{array}$ \\
\hline $\begin{array}{l}\text { Lillemoe et } \\
\text { al., } 1993^{53} \text {. }\end{array}$ & $\begin{array}{l}\text { Prospective, } \\
\text { randomized, } \\
\text { double-blinded, } \\
\text { placebo- } \\
\text { controlled trial }\end{array}$ & $\begin{array}{l}\text { Patients with } \\
\text { suspected } \\
\text { unresectable } \\
\text { pancreatic cancer }\end{array}$ & 137 & $\begin{array}{l}\text { Chemical } \\
\text { splanchniectomy } \\
\text { with } 50 \% \text { alcohol } \\
\text { in saline vs. } 0.9 \% \\
\text { normal saline } \\
\text { injection during } \\
\text { surgical exploration }\end{array}$ & $\begin{array}{l}\text { Pain, mood, } \\
\text { and disability } \\
\text { score, survival } \\
\text { rate }\end{array}$ & $\begin{array}{l}20 \mathrm{ml} \text { of } 50 \% \\
\text { alcohol bilaterally }\end{array}$ & $\begin{array}{l}\text { Intraoperative chemical splanchniectomy with } \\
\text { alcohol resulted in significant improvement in } \\
\text { mean pain score at } 2-, 4-, \text { and } 6-m o n t h, \text { and final } \\
\text { assessment within } 2 \text { months of death compared } \\
\text { to control group. Patients who received alcohol } \\
\text { treatment had significantly longer duration of } \\
\text { pain relief, lower narcotic requirement, and less } \\
\text { likely to have severe pain at death. Scores for } \\
\text { disability and mood progressively worsened over } \\
\text { the clinical course of disease for all patients. No } \\
\text { significant difference was found in mood and } \\
\text { disability score between the alcohol and control } \\
\text { group. Survival was found to be markedly } \\
\text { improved in alcohol group when compared to } \\
\text { control group ( } p<0.0001) \text {. }\end{array}$ & $\begin{array}{l}\text { There were two cases with } \\
\text { transient episodes of hypertension } \\
\text { without sequelae during } \\
\text { alcohol injection. There was no } \\
\text { complication associated with } \\
\text { hypotension or bleeding following } \\
\text { any celiac plexus injection. }\end{array}$ & $\begin{array}{l}\text { Intraoperative chemical } \\
\text { splanchniectomy with } \\
\text { alcohol should be } \\
\text { advocated for all patients } \\
\text { with unresectable } \\
\text { pancreatic cancer. }\end{array}$ \\
\hline $\begin{array}{l}\text { Kawamata et } \\
\text { al., } 1996^{54} .\end{array}$ & $\begin{array}{l}\text { Randomized } \\
\text { controlled trial }\end{array}$ & $\begin{array}{l}\text { Patients with } \\
\text { advanced } \\
\text { pancreatic cancer }\end{array}$ & 21 & NCPB vs. SAT & $\begin{array}{l}\text { VAS pain score, } \\
\text { morphine } \\
\text { consumption, } \\
\text { performance } \\
\text { status, and self- } \\
\text { assessed QoL } \\
\text { scores }\end{array}$ & $\begin{array}{l}15-20 \mathrm{ml} \text { of } 80 \% \\
\text { alcohol bilaterally }\end{array}$ & $\begin{array}{l}\text { VAS score was significantly lower for the first } \\
4 \text { weeks after NCPB compared to NSAID- } \\
\text { Morphine treatment. Morphine consumption was } \\
\text { found to be significantly lower in NCPB group } \\
\text { than those in NSAID-morphine group at 4-7 } \\
\text { weeks post-procedure. Statistically significant } \\
\text { improvement in performance status was found } \\
\text { only at } 4^{\text {th }} \text { week between the two groups. }\end{array}$ & $\begin{array}{l}\text { Symptoms of loss of appetite } \\
\text { at } 6^{\text {th }} \text { and } 8^{\text {th }} \text { week and nausea } \\
\text { at } 8^{\text {th }} \text { week were found to be } \\
\text { significantly higher in NSAID- } \\
\text { morphine group. }\end{array}$ & $\begin{array}{l}\text { Improvement in pain } \\
\text { management may not } \\
\text { correlate with better } \\
\text { quality of life in advanced } \\
\text { pancreatic cancer patients. }\end{array}$ \\
\hline $\begin{array}{l}\text { Polati et al., } \\
1998^{55} \text {. }\end{array}$ & $\begin{array}{l}\text { Prospective, } \\
\text { randomized } \\
\text { double-blind } \\
\text { trial }\end{array}$ & $\begin{array}{l}\text { Patients with } \\
\text { unresectable } \\
\text { pancreatic } \\
\text { adenocarcinoma }\end{array}$ & 24 & NCPB vs. SAT & $\begin{array}{l}\text { VAS pain } \\
\text { score, mean } \\
\text { consumption } \\
\text { of diclofenac } \\
\text { sodium and } \\
\text { opioids }\end{array}$ & $\begin{array}{l}7 \mathrm{ml} \text { of absolute } \\
\text { alcohol via each } \\
\text { needle }\end{array}$ & $\begin{array}{l}\text { Primary endpoint was immediate }(24-48 \mathrm{~h}) \text { and } \\
\text { long-term efficacy of the treatment until death. } \\
\text { Complete pain relief at } 24-\text { and } 48 \text {-h interval was } \\
\text { reported in } 9 \text { out of } 12 \text { patients in NCPB group } \\
\text { but only } 2 \text { out of } 12 \text { patients in pharmacological } \\
\text { therapy group. However, long-term pain relief } \\
\text { was not significant between the two groups. } \\
\text { Mean consumption of NSAID and opioid was } \\
\text { significantly lower in NCPB group }\end{array}$ & $\begin{array}{l}\text { Transient diarrhea and orthostatic } \\
\text { hypotension were observed in } 3 \\
\text { and } 5 \text { patients who underwent } \\
\text { NCPB, respectively. }\end{array}$ & $\begin{array}{l}\text { Neurolytic celiac plexus } \\
\text { block can abolish visceral } \\
\text { celiac type of cancer- } \\
\text { related pain in a significant } \\
\text { portion of pancreatic cancer } \\
\text { patients. It also reduces the } \\
\text { incidence of drug-related } \\
\text { adverse events due to lower } \\
\text { opioid consumption. }\end{array}$ \\
\hline $\begin{array}{l}\text { Staats et al., } \\
2001^{14} \text {. }\end{array}$ & $\begin{array}{l}\text { Prospective, } \\
\text { randomized, } \\
\text { double-blind, } \\
\text { controlled trial }\end{array}$ & $\begin{array}{l}\text { Patients with } \\
\text { unresectable } \\
\text { pancreatic cancer }\end{array}$ & 139 & $\begin{array}{l}\text { Chemical } \\
\text { splanchniectomy } \\
\text { with } 50 \% \text { alcohol } \\
\text { in saline vs. } 0.9 \% \\
\text { normal saline } \\
\text { injection during } \\
\text { surgical exploration }\end{array}$ & $\begin{array}{l}\text { VAS pain } \\
\text { score, mood } \\
\text { score, pain } \\
\text { interference } \\
\text { with activities } \\
\text { of daily living, } \\
\text { survival rate }\end{array}$ & $\begin{array}{l}20 \mathrm{ml} \text { of } 50 \% \\
\text { alcohol bilaterally }\end{array}$ & $\begin{array}{l}\text { There was significant reduction in VAS pain } \\
\text { score in alcohol group compared to saline } \\
\text { group. Alcohol block also significantly improved } \\
\text { longevity compared to saline block. High } \\
\text { negative mood patients were correlated to } \\
\text { more pain interference with daily activities. } \\
\text { Postoperative pain score was found to be } \\
\text { inversely correlated with longevity, and the } \\
\text { correlation was significant. }\end{array}$ & N/A & $\begin{array}{l}\text { Bilateral splanchniectomy } \\
\text { with alcohol during surgical } \\
\text { laparotomy improved } \\
\text { pain, mood, activities, and } \\
\text { longevity in pancreatic } \\
\text { cancer patients. }\end{array}$ \\
\hline $\begin{array}{l}\text { Özyalçin et } \\
\text { al., 200471. }\end{array}$ & $\begin{array}{l}\text { Prospective, } \\
\text { single blind, } \\
\text { randomized } \\
\text { trial }\end{array}$ & $\begin{array}{l}\text { Pancreatic } \\
\text { cancer patients } \\
\text { with tumor } \\
\text { involvement of } \\
\text { body and/or tail of } \\
\text { pancreas }\end{array}$ & 39 & $\begin{array}{l}\text { Celiac plexus block } \\
\text { vs. splanchnic } \\
\text { nerve block }\end{array}$ & $\begin{array}{l}\text { VAS pain } \\
\text { score, opioid } \\
\text { consumption, } \\
\text { QoL, survival } \\
\text { rate }\end{array}$ & $\begin{array}{l}40 \mathrm{ml} \text { of } 75 \% \\
\text { ethanol for NCPB } \\
\text { and } 6 \mathrm{ml} \text { of } 75 \% \\
\text { ethanol for bilateral } \\
\text { splanchnic nerve } \\
\text { blockade }\end{array}$ & $\begin{array}{l}\text { Splanchnic nerve block provided significantly } \\
\text { greater VAS difference, lower opioid } \\
\text { requirement, and greater survival rate than } \\
\text { celiac plexus block. However, QoL was found to } \\
\text { be insignificant between the two groups. }\end{array}$ & $\begin{array}{l}\text { Two patients in celiac group and } \\
\text { one patient in splanchnic group } \\
\text { reported severe pain during } \\
\text { procedure. Five patients in } \\
\text { celiac group developed transient } \\
\text { diarrhea. Two patients in celiac } \\
\text { group required inotropic support } \\
\text { for hemodynamic instability. }\end{array}$ & $\begin{array}{l}\text { Splanchnic nerve blockade } \\
\text { may be more effective than } \\
\text { celiac plexus blockade in } \\
\text { patients with advanced } \\
\text { cancer with tumor involving } \\
\text { the pancreatic body and tail. }\end{array}$ \\
\hline $\begin{array}{l}\text { Wong et al., } \\
2004^{56} \text {. }\end{array}$ & $\begin{array}{l}\text { Prospective, } \\
\text { double-blind, } \\
\text { randomized } \\
\text { controlled trial }\end{array}$ & $\begin{array}{l}\text { Patients with } \\
\text { unresectable } \\
\text { pancreatic cancer }\end{array}$ & 100 & NCPB vs. SAT & $\begin{array}{l}\text { NRS pain } \\
\text { score, opioid } \\
\text { consumption, } \\
\text { QoL, survival } \\
\text { time }\end{array}$ & $\begin{array}{l}10 \mathrm{ml} \text { of absolute } \\
\text { alcohol via each } \\
\text { needle }\end{array}$ & $\begin{array}{l}\text { Mean pain intensity was significantly reduced in } \\
\text { both groups as early as } 1 \text { week after treatment. } \\
\text { The reduction in pain was significantly greater in } \\
\text { NCPB than SAT group. QoL gradually declined } \\
\text { after one-week post-treatment in both groups } \\
\text { with no significant difference between the two } \\
\text { groups. Opioid consumption increased over } \\
\text { time with no difference between the two groups. } \\
\text { No significant difference in survival was found } \\
\text { between treatment groups. }\end{array}$ & $\mathrm{N} / \mathrm{A}$ & $\begin{array}{l}\text { NCPB improves pain relief } \\
\text { in patients with pancreatic } \\
\text { cancer compared to SAT } \\
\text { but not QoL and survival. }\end{array}$ \\
\hline $\begin{array}{l}\text { Jain et al., } \\
2005^{57} \text {. }\end{array}$ & $\begin{array}{l}\text { Prospective } \\
\text { controlled trial }\end{array}$ & $\begin{array}{l}\text { Patients with } \\
\text { advanced upper } \\
\text { abdominal } \\
\text { malignancies }\end{array}$ & 100 & NCPB vs. SAT & $\begin{array}{l}\text { VAS pain score, } \\
\text { morphine } \\
\text { consumption, } \\
\text { QoL }\end{array}$ & $\begin{array}{l}20 \mathrm{ml} \text { of } 50 \% \\
\text { alcohol }\end{array}$ & $\begin{array}{l}\text { VAS score was significantly lower in NCPB } \\
\text { group than that of control group at } 7 \text { and } 30 \\
\text { days after treatment. Morphine consumption was } \\
\text { significantly lower in NCPB group compared to } \\
\text { that of control group at } 30 \text { days after treatment. } \\
\text { Quality of life was significantly improved in } \\
\text { NCPB group but not statistically different from } \\
\text { control group at } 30 \text { days. }\end{array}$ & $\begin{array}{l}\text { Celiac plexus neurolysis } \\
\text { statistically lowers pain intensity, } \\
\text { reduces morphine consumption, } \\
\text { and improves QoL at } 30 \text {-day } \\
\text { interval, but there was no } \\
\text { significant difference in QoL when } \\
\text { compared with morphine group }\end{array}$ & $\begin{array}{l}\text { Side effects of treatment } \\
\text { were significantly higher in } \\
\text { morphine group. }\end{array}$ \\
\hline $\begin{array}{l}\text { Zhang et al., } \\
2008^{58} \text {. }\end{array}$ & $\begin{array}{l}\text { Prospective } \\
\text { randomized } \\
\text { controlled } \\
\text { study }\end{array}$ & $\begin{array}{l}\text { Patients with } \\
\text { unresectable } \\
\text { pancreatic cancer }\end{array}$ & 56 & $\begin{array}{l}\text { CT-guided NCPB } \\
\text { vs. SAT }\end{array}$ & $\begin{array}{l}\text { VAS pain } \\
\text { score, opioid } \\
\text { consumption, } \\
\text { QoL }\end{array}$ & $\begin{array}{l}20 \mathrm{ml} \text { of absolute } \\
\text { alcohol }\end{array}$ & $\begin{array}{l}\text { Patients who underwent NCPB had significantly } \\
\text { lower VAS pain score than those at } 1,7, \text { and } \\
14 \text { days. Opioid consumption was significantly } \\
\text { lower in NCPB than control group at day } 7, \\
14,30,60 \text {, and } 90 \text { days. Quality of life was } \\
\text { significantly improved after treatment, but no } \\
\text { significant difference was found between the } \\
\text { two groups. }\end{array}$ & $\begin{array}{l}\text { Orthostatic hypotension, } \\
\text { drunkenness symptoms, diarrhea, } \\
\text { and burning pain at needle entry } \\
\text { site were reported. Only } 6 \text { patients } \\
\text { who underwent NCPB had } \\
\text { nausea and vomiting compared to } \\
22 \text { patients in control group, which } \\
\text { was significantly different. }\end{array}$ & $\begin{array}{l}\text { CT-guided NCPB is safe } \\
\text { and effective modality for } \\
\text { cancer-related pain relief in } \\
\text { advanced pancreatic cancer } \\
\text { patients. }\end{array}$ \\
\hline
\end{tabular}

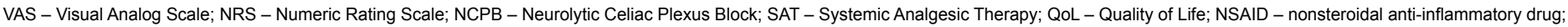
CT - Computed Tomography; N/A - not applicable 
the inter-patient discrepancy between partial and complete pain relief could be multi-fold and possibly related to incomplete destruction of the celiac plexus. As demonstrated by postmortem neurohistological studies of the celiac plexus, evidence of perineural fibrosis, shrunken-looking neurons, normal-appearing nerve fibers, and lymphocytes in pancreatic cancer patients after NCPB implied the very common nature of incomplete celiac neurolysis. 60 Other proposed theories included the coexistence of more than one source of pain, insufficient spread of neurolytic agent, and migration of tumor cells into surrounding tissues. ${ }^{51}$

One multi-centered study prospectively examined the predictors of successful response to NCPB in 22 patients with pancreatic cancer pain. Mercadante and associates concluded that the experience of the physician and local spread of the tumor are likely the predominant factors contributing to the outcomes of NCPB. ${ }^{61}$ Unsatisfactory responses to repeated trials of NCPB have also been demonstrated by $\mathrm{CT}$ in patients with massive invasion and metastases around the celiac axis. ${ }^{62} \mathrm{~A}$ pilot study conducted by McGreevy et al. also confirmed the significance of disease progression and metastases in predicting the outcome for repeat NCPB. ${ }^{63}$ De Cicco et al. divided the celiac axis into four quadrants and demonstrated that only complete neurolytic spread of all four quadrants could guarantee long-lasting analgesia, indicating the clinical significance of injectate spread for predicting the efficacy of NCPB. ${ }^{64}$ Furthermore, Rykowski et al. revealed that the location of the pancreatic tumor was an independent prognostic factor for predicting the efficacy of NCPB. Of the 37 patients (74\%) who responded favorably to NCPB, 33 patients had a tumor involving the head of pancreas and four patients had a tumor involving the body and tail of the pancreas. ${ }^{62}$ Their findings suggested that the location of tumor involvement in the pancreas correlates to disease progression and alters the efficacy of NCPB.

It is interesting to note that regardless of whether radiographic guidance was used for NCPB, Eisenberg et al. reported no difference in the rate of successful blockade and incidence of adverse events. ${ }^{59}$ Similarly, McGreevy et al. compared CT-guided to fluoroscopy-guided NCPB and reported no significant difference between responders and non-responders to repeat NCPB. ${ }^{63}$ However, Erdek et al. found that NCPB with CT-guidance was correlated with positive outcomes, but the results were marginally significant $(p<0.06) .{ }^{65}$ Compared to fluoroscopy, CT provides images with higher spatial resolution and thereby enhances visualization of the celiac ganglia, tumor burden, and needle position. Despite higher radiation exposure from $\mathrm{CT}$, these advantages assuredly attribute to the higher likelihood of achieving superior analgesia from NCPB. Overall, Eisenberg et al. concluded that NCPB is a relatively safe intervention for short- and long-term palliation of cancer-related pain in patients with intraabdominal malignancies.

A 2007 review by Yan and Myers included 302 patients from 5 RCTs conducted during the period extending from 1966 to $2005 .{ }^{66}$ The authors found only $6 \%$ reduction in pain intensity from NCPB compared to baseline pain score. Nevertheless, there was a significant mean reduction of 40 to $80 \mathrm{mg}$ daily dose of opioid in NCPB compared to SAT at two, four and eight weeks, which was based on data extracted from three studies. ${ }^{52,54,56}$ Similar to Eisenberg et al., the authors concluded that NCPB is a safe technique to be incorporated in the standard treatment of patients with inoperable pancreatic cancer for effective reduction in pain intensity, analgesic requirements, and opioid-induced constipation. ${ }^{66}$ Another systematic review by Moor and Adler was performed in $2009 .{ }^{67}$ However, no literature search criteria were described for the selection of appropriate studies. Regardless, they also concluded that NCPB is a safe technique that provides long-lasting, opioid-sparing benefits in pancreatic cancer patients.

A Cochrane Review by Arcidiacono et al. evaluated 358 participants included in six RCTs. ${ }^{68}$ There was profound reduction in opioid consumption, lower incidence of diarrhea or constipation, and improvement in immediate pain relief with a weighted mean difference of -0.42 at four weeks between NCPB and SAT groups $(p=0.004)$. Despite the lack of strong evidence supporting the therapeutic superiority of NCPB over SAT in pancreatic cancer patients, the authors highlighted the clinical significance of incorporating NCPB as an opioid-sparing strategy to abate opioid-related adverse effects.

A systematic review by Nagels et al. identified five RCTs, which included results for 295 patients. ${ }^{69}$ The meta-analysis demonstrated significant differences of -0.87 and -0.47 in pain reduction when NCPB $(n=149)$ was compared to SAT $(n=146)$ at one to two weeks $(p=0.004)$ and four weeks ( $p=$ $0.0001)$, respectively. However, significant differences in pain intensity between the two groups dissipated at $8(p=0.16)$ and 12 weeks in four and two relevant studies, respectively. Both NCPB and SAT groups exhibited significant reduction of opioid consumption compared to baseline. Significant difference in the reduction of opioid consumption was also found between the two groups at all of the time intervals. The mean difference in morphine usage was reported to be -44.64 at one to two weeks $(p=0.002),-72.41$ at 4 weeks $(p<0.00001)$, and -65.69 at eight weeks $(p<0.0001)$. Only one study had data available at 12 weeks, which reported a significantly lower consumption of morphine in NCPB group compared to SAT group (105 $\pm 65 \mathrm{mg}$ vs. $169 \pm 71 \mathrm{mg} ; p<0.01)$. The authors concluded that percutaneous NCPB is safe and capable of delivering superior analgesic benefits to patients with advanced upper intra-abdominal cancer.

Another meta-analysis by Zhong et al. examined 7 RCTs, which included 196 patients who met eligibility criteria.70 Among the four studies with the assessment of pain score at four weeks, there was a statistically significant mean difference in pain score of -0.382 between NCPB $(\mathrm{n}=99)$ and SAT $(\mathrm{n}$ $=98)(p=0.005)$. At 8 weeks, the statistical significance of mean difference in pain score between NCPB $(n=184)$ and SAT $(n=195)$ was no longer maintained based on 6 relevant studies. Regarding the use of pharmacological analgesics, there was a mean difference of $-49.77(p=0.005)$ and -48.29 $(p<0.001)$ between NCPB and SAT groups at four weeks and one day before death, respectively, based on five relevant studies. Of the studies included in this meta-analysis, NCPB was performed by percutaneous NCPB, EUS-guided NCPB, thoracoscopic splanchniectomy, and intraoperative chemical splanchniectomy. The impact of these approaches to performing NCPB on the efficacy of pain relief remains largely unknown due to the dearth of comparative studies among these interventions. ${ }^{69}$ In summary, albeit concerns about the potential effects of confounding bias, this systematic review demonstrated statistically significant short-term (four weeks) efficacy of NCPB in cancer-related pain and that the efficacy was further supported by significantly decreased consumption of opioid and NSAIDs. ${ }^{69,70}$
Efficacy of Celiac Plexus Neurolysis vs. Splanchnic Nerve Neurolysis Innervations of the upper abdominal viscera are mediated by sensory afferent and sympathetic efferent fibers via the splanchnic nerves and celiac ganglia. ${ }^{23}$ Theoretically, blockade of either the celiac ganglia or splanchnic nerves will deter nociceptive 
transmission of the upper abdominal viscera. A total of two prospective, randomized, comparative studies of percutaneous celiac plexus and splanchnic nerve blockade on the efficacy of cancer-related pain relief were found in the literature. Ischia and colleagues explored the efficacy of percutaneous NCPB using three different techniques, namely, transaortic celiac plexus block, classic retrocrural block, and bilateral chemical splanchiectomy on pain relief. They found no significant difference in pain reduction among the three techniques. ${ }^{51}$

\section{Özyalçin and colleagues conducted a} comparative study on the efficacy of celiac plexus and splanchnic nerve blockades in pancreatic cancer patients. ${ }^{71}$ This prospective, single-blinded, randomized study enrolled 39 patients with pancreatic adenocarcinoma. Patients who received bilateral splanchnic nerve blockade reported a significantly greater VAS pain score reduction than those with celiac plexus blockade up to 12-weeks after intervention $(p \leq 0.002)$. These patients also had a more substantial decrease in total daily codeine requirement up to 10 weeks after treatment $(p \leq 0.041)$ and increase in survival rate $(p=0.0072)$. Surprisingly, no difference in QoL was clinically observed between celiac and splanchnic nerve blocks. The authors concluded that splanchnic nerve blocks may be a viable alternative to celiac plexus block based on statistically better outcomes in pain reduction, opioid usage and longevity. These two small, but otherwise good quality trials did not provide sufficient evidence that celiac plexus and splanchnic nerve neurolysis differ in their relative efficacy.

\section{Effect of Celiac Plexus Neurolysis on Quality} of Life and Survival

Despite the clinical benefit in the palliation of cancer-related pain, the effect of NCPB on QoL and survival in patients with advanced intraabdominal malignancies remains largely controversial. Kawamata et al. performed a pilot study comparing NCPB with SAT on the effect of QoL. ${ }^{54}$ Despite profound reduction in pain and opioid consumption in NCPB group, QoL only improved at the two-week interval. Gradual deterioration in QoL was observed over time with disease progression. We can infer that pain severity and opioid use do not wholly contribute to QoL, which can also be influenced by physiological variables, symptom status, functional health and general health perceptions. ${ }^{72}$ Both Jain et al. and Zhang et al. found that as an effective analgesic intervention, NCPB provided no significant difference in improving QoL compared to opioids alone. ${ }^{57,58}$ Despite these discouraging outcomes, most practitioners remain inclined to attribute the experience of suboptimal pain control to deleterious effects on all aspects of QoL in cancer patients of all stages.

Cancer-related pain is a common and highly debilitating symptom associated with functional, cognitive, and psychological impairments. ${ }^{3,73}$ Theoretically, optimal pain control should promote restoration of physical well-being and functional capacity in cancer patients. With less psychological distress, fatigue, and functional impairment, cancer patients can undergo therapies to ease symptoms and prolong survival. ${ }^{73}$ Ischia and colleagues found no significant difference in survival times in 61 patients with unresectable pancreatic cancer after NCPB.51 Surprisingly, Lillemoe et al. evaluated 137 patients and found that survival was markedly improved with alcohol splanchniectomy compared to those in the saline group $(p<0.0001) \cdot{ }^{53}$ Staats et al. completed a randomized control trial involving 139 participants with unresectable pancreatic cancer. ${ }^{74}$ Among 130 patients who completed the study, it was noted that NCPB with alcohol during laparotomy had a significantly positive impact on longevity compared to those with saline $(p<0.01)$. The study also found a negative correlation between post-procedural cancer-related pain and survival. The authors postulated that improved survival might be attributed to better QoL including better sleep quality and appetite, improved mood, enhanced functional capacity and reduced risks of thrombotic events.

Despite the encouraging outcomes on longevity by Staat et al. and Lillemoe et al., Wong and colleagues conducted a randomized control trial with contradictory findings. ${ }^{56}$ Their study evaluated the effect of NCPB on pain relief, QoL, and survival in 100 patients with unresectable pancreatic cancer. Despite significant short-term pain reduction, NCPB did not offer significant benefits on either QoL $(p=0.46)$ or survival $(p=0.26)$ within the 12-week follow-up period. QoL was found to gradually decrease with time. By the end of the double-blind phase, only $16 \%$ of NCPB patients and $6 \%$ of SAT patients remained alive, with no significant difference in survival rate between the two groups, implying the lack of correlation between pain reduction and survival.

Özyalçin and colleagues compared the analgesic efficacy of celiac plexus block and splanchnic nerve block and reported no significant difference in QoL between the two groups on the basis of performance status and patient satisfaction. ${ }^{71}$ Interestingly, patients with tumor involving the body and/ or tail of pancreas who underwent splanchnic nerve blockade had significantly higher mean survival rate (68.85 \pm SE 7.3 days) than those who underwent celiac plexus blockade (45.37 \pm SE 5.82 days; $p=0.0072$ ). The results implied that greater pain reduction, lower opioid consumption and longer lifeexpectancy in the splanchnic group may be independent of QoL.

In a systematic review by Yan and Myers, the evidence did not support any clinical benefits in survival rates and QoL despite better pain control and less opioid use from NCPB. ${ }^{66} \mathrm{In}$ a more recent systematic review by Nagels, ${ }^{69}$ improved QoL score from baseline was detected initially in two relevant studies but deteriorated gradually over time with disease progression..$^{5471}$ None of the RCTs exhibited any significant difference in QoL between percutaneous NCPB and SAT.

Overall, NCPB has not convincingly been demonstrated to improve QoL and prolong survival in patients with upper intra-abdominal malignancies. These findings may be due to tumor progression in advanced disease. A recent preclinical study has provided insights into the basis of neural-tumor interactions. Saloman et al. demonstrated that sensory neuron ablation by injection of capsaicin in two mouse models of pancreatic ductal adenocarcinoma prevented neurogenic inflammation, delayed tumor progression and significantly prolonged survival ( 7.80 vs. 4.53 months, $p=0.0001) .{ }^{75}$ Denervation of primary afferents that innervate the pancreas can block perineural invasion, astrocyte activation and neuronal damage, resulting in suppression of tumorigenesis in early stages of pancreatic cancer. ${ }^{76}$ These experimental findings support the clinical significance of NCPB in the early stages of pancreatic cancer to prolong survival, and explain the minimal benefits on overall survival in patients with inoperable pancreatic cancer.

\section{Volume of Neurolytic Agents in Celiac Plexus Blockade}

Neurolytic agents, especially alcohol, have been described to cause neural destruction of the celiac/splanchnic plexus for pain relief in cancer patients. However, optimal volume of neurolytic agent remains to be established. In clinical practice, administration of 10-80 $\mathrm{ml}$ of alcohol has been cited for NCPB, with typical volumes ranging from 20 to $40 \mathrm{ml} .^{77,78}$ Within the literature, there is only one RCT exploring the effect of different volumes of alcohol on cancer-related pain reduction. ${ }^{79}$ Dolly and colleagues selected 30 patients with 
upper abdominal malignancies as candidates for NCPB. The results showed that 20, 30, and $40 \mathrm{ml}$ of $70 \%$ alcohol provided a duration of blockade lasting eight, 12, and 16 weeks, respectively. Forty mililiters of injectate was found to have a significantly lower morphine requirement and higher QoL scores compared to 20 and $30 \mathrm{ml}$. These outcomes validated the rationale proposed by De Cicco et al. that thorough spread of alcohol, involving all four quadrants of the celiac axis, was essential to achieve complete pain relief. ${ }^{64}$ Therefore, the possibility of volume to affect the spread of neurolytic agent is certainly plausible for predicting the outcome in pain reduction, analgesic usage and QoL. Given the paucity of studies further large-scale randomized trials are needed to address the optimal volume of neurolytic agent to administer during NCPB.

Types of Neurolytic agents in Celiac Plexus Blockade

Neurolytic agents such as phenol and alcohol have been used extensively to induce disintegrative nerve changes via Wallerian degeneration, promoting long-lasting analgesia, reportedly up to six months. ${ }^{80,81,82,83}$ The extent and duration of analgesia after ablation are frequently limited by axonal regeneration, which begins within three to six months at a rate of 1 to $1.5 \mathrm{~mm}$ per week. $^{80,81,82,83,84}$ Concentrations of $50-100 \%$ alcohol and 6-10\% phenol have been used successfully for chemical ablation of neural structures. ${ }^{24,85}$ Koyyalagunta and colleagues retrospectively evaluated 93 patients with abdominal cancer pain. ${ }^{86}$ The authors found no significant difference in pain reduction at one month between alcohol and phenol use for NCPB $(p=0.66)$. There was also no difference in complications between the two agents. The authors demonstrated that both neurolytic agents were equally effective and safe for cancer-related pain relief. With limited evidence, prospective randomized studies are needed to validate that both alcohol and phenol are equally effective in NCPB.

\section{Safety of Celiac Plexus Neurolysis}

Eisenberg et al. reported that adverse events including local pain (96\%), diarrhea (44\%), and hypotension (38\%) were common but transient, self-limited and of mild severity. ${ }^{59}$ Severe neurological complications accounted for an estimated incidence of $1 \%$ and included lower extremity weakness, paresthesia, epidural anesthesia and lumbar puncture. Other non-neurological complications accounted for an additional $1 \%$. These included pneumothorax, shoulder, chest and pleuritic pain, hiccoughing and hematuria.
Yan and Myers found no significant difference in nausea, vomiting, diarrhea and sedation among treatment groups, but constipation was significantly less in NCPB group. ${ }^{66}$ Orthostatic hypotension was more common in the NCPB group, but the difference between treatment groups was not statistically significant ( $p=$ $0.09)$.

Recently, a meta-analysis was performed for analyzing diarrhea, constipation, hypotension, and nausea and vomiting for percutaneous NCPB. ${ }^{69}$ The incidence of diarrhea $(p=$ $0.0003)$ and hypotension $(p=0.0003)$ were significantly higher in NCPB than SAT. The results were not surprising as sympatholytic agents were known to cause hypotension. Diarrhea was common due to unopposed stimulation of the parasympathetic nervous system. ${ }^{86}$ Conversely, the incidence of constipation, nausea and vomiting were significantly lower in NCPB than SAT ( $p<$ 0.0001 ), suggesting opioid-sparing effect of NCPB. ${ }^{66}$

Other less common side effects included local pain at needle puncture site $(7-29 \%)$, back pain $(5-60 \%)$, shoulder pain $(6-9 \%)$, signs of alcohol intoxication (7-22.4\%), pneumothorax (1-3\%), reactive pleurisy or pleural effusion (5-8\%), transient dysesthesias (0.3-7\%), transient neuritis $(2-37 \%)$, permanent foot drop (1.5\%), transient monoparesis $(0.3 \%)$, peritonitis $(6 \%)$ and hematuria $(<2-$ $6 \%$ )66. Permanent, partially reversible and completely reversible paraplegia have also been reported. ${ }^{66}$

Davies conducted a survey of 160 pain clinics in England and Wales that performed NCPB over a 5 year period (1986-1990) They noted that 4 out of 2730 NCPB patients developed permanent paraplegia ${ }^{87}$ Postulated mechanisms for the resulting paraplegia included inadvertent seepage or injection of neurolytic agent into the cerebrospinal fluid and impaired blood supply to the spinal cord due to injury or spasm of the artery of Adamkiewicz. The estimated incidence of permanent paraplegia accounted for approximately $0.15 \%$. Other rare complications such as sexual dysfunction, ${ }^{88}$ retroperitoneal hematoma, ${ }^{89}$ abdominal aortic dissection, ${ }^{90}$ chylothorax, ${ }^{91}$ diaphragmatic paralysis, ${ }^{92}$ and hemorrhagic gastritis and duodenitis ${ }^{93}$ had all been reported. Despite considerable risks of major complications, NCPB is widely considered to be a safe procedure because operative mortality and catastrophic complications remain exceedingly rare.

\section{Conclusion}

Neurolytic blockade of the celiac/splanchnic plexus can be used safely in cancer patients for analgesic control. It provides superior pain control and an analgesic-sparing effect in patients with advanced intraabdominal malignancies up to six months, particularly when combined with SAT. At the present time, the data concerning NCPB for improved survival and QoL are inconsistent and less compelling. There is also no evidence of superiority for neurolysis of celiac plexus or splanchnic nerves. Predictive factors contributing to the efficacy of NCPB include disease progression, metastases, operator experience, location of tumor, tumor burden and injectate spread. The use of alcohol and phenol appear to be equally effective for cancer-related pain relief. The optimal volume of neurolytic agent remains controversial, but $40 \mathrm{ml}$ of alcohol appears to yield adequate extent of longitudinal spread along the celiac axis. We conclude that early application of NCPB should be encouraged to serve as a supplement to multimodal analgesia for malignant pain in patients with advanced disease. The decision to employ NCPB should always be individualized, by incorporating patients' preferences and weighing the risk/ benefit profiles.

https://doi.org/10.32873/unmc.dc.gmerj.2.2.005

\section{References}

1 Siegel RL, Miller KD, Jemal A. Cancer Statistics, 2017. CA Cancer J Clin 2017; 67:7-30.

2 Arslan D, Koca T, Akar E, Tural D, Ozdogan M. Cancer pain prevalence and its management. Asian Pac J Cancer Prev 2014; 15:8557-8562.

3 Jacox A, Carr DB, Payne R. New clinical-practice guidelines for the management of pain in patients with cancer. N Engl J Med 1994; 330:651-655.

4 Blinderman CD, Billings JA. Comfort care for patients dying in the hospital. N Engl J Med 2015; 373:25492561 .

5 Chari ST. Detecting early pancreatic cancer: problems and prospects. Semin Oncol 2007; 34:284-294.

6 Pharo GH, Zhou L. Pharmacological management of cancer pain. JAOA 2005; 105:S21-28.

7 Miguel R. Interventional treatment of cancer pain: the fourth step in the World Health Organization analgesic ladder? Cancer Control 2000; 7:149-156.

8 Dubin AE, Patapoutian A. Nociceptors: the sensors of the pain pathway. $J$ Clin Invest 2010; 120:3760-3772.

9 Rigor BM Sr. Pelvic cancer pain. J Surg Oncol 2000; 75:280-300.

10 Nersesyan H, Slavin KV. Current approach to cancer pain management: Availability and implications of different treatment options. Ther Clin Risk Manag 2007; 3:381-400.

11 Mishra S, Bhatnagar S, Gupta D, Nirwani Goyal G, Jain R, Ghauhan H. Management of neuropathic cancer pain following WHO analgesic ladder: a prospective study. Am J Hosp Palliat Care 2008; 25:447-451.

12 Demir IE, Ceyhan GO, Rauch U, Altintas B, Klotz M, Müller MW, Büchler MW, Friess H, Schäfer $\mathrm{KH}$. The microenvironment in chronic pancreatitis 
and pancreatic cancer induces neuronal plasticity. Neurogastroenterol Motil 2010; 22:480-490.

13 Johnson C, Birtwistle J, Davis C. Pain in upper abdominal malignancy. Turk J Med Sci 2007; 37:327331.

14 van den Beuken-van Everdingen MHJ, de Rijke JM, Kessels AG, Schouten HC, van Kleef M, Patijn J. Prevalence of pain in patients with cancer: a systematic review of the past 40 years. Ann Oncol 2007; 18:1437-1449.

15 Ahmedzai S. Current strategies for pain control. Ann Oncol 1997; 8:S21-24.

16 Aich A, Gupta P, Gupta K. Could perioperative opioid use increase the risk of cancer progression and metastases? Int Anesthesiol Clin 2016; 54:e1-e16.

17 Zylla D, Steele G, Gupta P. A systematic review of the impact of pain on overall survival in patients with cancer. Support Care Cancer 2017; 25:1687-1698.

18 Zhang XY, Liang YX, Yan Y, Dai Z, Chu HC. Morphine: double-faced roles in the regulation of tumor development. Clin Transl Oncol 2017. http:// doi.org/10.1007/s12094-017-1769-x.

19 Saloman JL, Albers KM, Li D, Hartman DJ, Crawford HC, Muha EA, Rhim AD, Davis BM Ablation of sensory neurons in a genetic model of pancreatic ductal adenocarcinoma slows initiation and progression of cancer. PNAS 2016; 113:3078-3083.

20 Pour PM, Bell RH, Batra SK. Neural invasion in the staging of pancreatic cancer. Pancreas 2003; 26:322325 .

21 Ceyhan GO, Demir IE, Altintas B, Rauch U, Thiel G, Müller MW, Giese NA, Friess H, Schäfer KH. Neural invasion in pancreatic cancer: a mutual tropism between neurons and cancer cells. Biochem Biophys Res Commun 2008; 374:442-447.

22 Liu B, Lu KY. Neural invasion in pancreatic carcinoma. Hepatobiliary Pancreat Dis Int 2002; 1:469-476.

23 Loukas M, Klaassen Z, Merbs W, Tubbs RS, Gielecki $\mathrm{J}$, Zurada A. A review of the thoracic splanchnic nerves and celiac ganglia. Clin Anat 2010; 23:512-522.

24 Mercadante S, Nicosia F. Celiac plexus block: a reappraisal. Reg Anesth Pain Med 1998; 23:37-48.

25 Nitschke AM, Ray CE Jr. Percutaneous neurolytic celiac plexus block. Semin Intervent Radiol 2013 30:318-321.

26 Kambadakone A, Thabet A, Gervais DA, Mueller PR, Arellano RS. CT-guided celiac plexus neurolysis: a review of anatomy, indications, technique, and tips for successful treatment. Radiographics 2011; 31:1599 1621

27 Brown DL, Moore DC. The use of neurolytic celiac plexus block for pancreatic cancer: anatomy and technique. J Pain Symptom Manage 1988; 3:206-209.

28 Singler RC. An improved technique for alcohol neurolysis of the celiac plexus. Anesthesiology 1982; 56: 137-141.

29 Boas RA. The sympathetic nervous system and pain. In: Swerdlow M (ed) Relief of intractable pain. 3rd ed. Elsevier, New York 1983, pp 215-237.

30 Ischia S, Luzzani A, Ischia A, Faggion S. A new approach to the neurolytic block of the coeliac plexus: the transacortic technique. Pain 1983; 16:333-341.

31 Ina H, Kitoh T, Kobyashi M, Imai S, Ofusa Y, Goto H. New technique for the neurolytic celiac plexus block: the transintervertebral disc approach. Anesthesiology $1996 ; 85: 212-217$

32 Liberman RP, Nance PN, Cuka DJ. Anterior approach to celiac plexus block during interventional biliary procedures. Radiology 1988; 167:562-564.

33 Romanelli DF, Beckmann CF, Heiss FW. Celiac plexus block: efficacy and safety of the anterior approach. AJR Am J Roentgenol 1993; 160:497-500.

34 Yamamuro M, Kusaka K, Kato M, Takahashi M. Celiac plexus block in cancer pain management. Tohoku J Exp Med 2000; 192:1-18.
35 Jones RR. A technic for injection of the splanchnic nerves with alcohol. Anesth Analg 1957; 36:75-77.

36 Trimble JA, Morrison S. Treatment of intractable pain of visceral origin. JAMA 1952; 48:84-88.

37 Bonica JJ. The role of the anaesthetist in the management of intractable pain. Proc R Soc Med 1954; 47:1029-1032.

38 Copping J, Willix R, Kraft R. Palliative chemical splanchnicectomy. Arch Surg 1969; 98:418-420.

39 Flanigan DP, Kraft RO. Continuing experience with palliative chemical splanchnicectomy. Arch Surg 1978, 113:509-511.

40 Sharp KW, Stevens EJ. Improving palliation in pancreatic cancer: intraoperative celiac plexus block for pain relief. South Med J 1991; 84:469-471.

41 Gardner AM, Solomon G. Relief of pain of unresectable carcinoma of the pancreas by chemical splanchnicectomy during laparotomy. Ann R Coll Surg 1984; 66:409-411

42 Erdine S. Celiac ganglion block. Agri 2005; 17:14-22.

43 Abbas H, Kohli M, Murali, Singh S, Singh V. Celiac plexus block - a palliative care for pancretic malignancy. The Internet Journal of Anesthesiology 2010; 29:1-5.

44 Moore DC, Bush WH, Burnett LL. Celiac plexus block: A roentgenographic, anatomic study of technique and spread of solution in patients and corpses. Anesth Analg 1981; 60:369.

45 Jain S. The role of celiac plexus block in intractable upper abdominal pain. In: Racz GB (ed). Techniques of Neurolysis. Kluwer Academic, Boston 1989, p 161.

46 Moore DC, Bush WH, Burnett LL. Celiac plexus block: a roentgenographic, anatomic study of technique and spread of solution in patients and corpses. Anesth Analg 1981; 60:369-379.

47 Fugère F, Lewis G. Coeliac block for chronic pain syndromes. Can J Anaesth 1993; 40:954-963.

48 Mohamed RE, Amin MA, Omar HM. Computed tomography-guided celiac plexus neurolysis for intractable pain of unresectable pancreatic cancer. The Egyptian Journal of Radiology and Nuclear Medicine 2017; 48:627-637.

49 Romanelli DF, Beckmann CF, Heiss FW. Celiac plexus block: efficacy and safety of the anterior approach. AJR Am J Roentgenol 1993; 160:497-500.

50 Kappis M. Erfahrungen mit lokalanasthesie be bauchoperationen. Verh Dtsch Ges Chir 1914; 43:8789.

51 Ischia S, Ischia A, Polati E, Finco G. Three posterior percutaneous celiac plexus block techniques. A prospective, randomized study in 61 patients with pancreatic cancer pain. Anesthesiology 1992; 76:534540.

52 Mercadante S. Celiac plexus block versus analgesics in pancreatic cancer pain. Pain 1993; 52:187-192.

53 Lillemoe KD, Cameron JL, Kaufman HS, Yeo CJ, Pitt HA, Sauter PK. Chemical splanchnicectomy in patients with unresectable pancreatic cancer. A prospective randomized trial. Ann Surg 1993; 217:447 455.

54 Kawamata M, Ishitani K, Ishikawa K, Sasaki H, Ota K, Omote K, Namiki A. Comparison between celiac plexus block and morphine treatment on quality of life in patients with pancreatic cancer pain. Pain 1996; 64:597-602.

55 Polati E, Finco G, Gottin L, Bassi C, Pederzoli P, Ischia $\mathrm{S}$. Prospective randomized double-blind trial of neurolytic coeliac plexus block in patients with pancreatic cancer. Br J Surg 1998; 85:199-201.

56 Wong GY, Schroeder DR, Carns PE, Wilson JL, Martin DP, Kinney MO, Mantilla CB, Warner DO. Effect of neurolytic celiac plexus block on pain relief, quality of life, and survival in patients with unresectable pancreatic cancer: a randomized controlled trial. JAMA 2004; 291:1092-1099.

57 Jain PN, Shrikhande SV, Myatra SN, Sareen R. Neurolytic celiac plexus block: a better alternative to opioid treatment in upper abdominal malignancies: an Indian experience. J Pain Palliat Care Pharmacother $2005 ; 19: 15-20$.

58 Zhang CL, Zhang TJ, Guo YN, Yang LQ, He MW Shi JZ, Ni JX. Effect of neurolytic celiac plexus block guided by computerized tomography on pancreatic cancer pain. Dig Dis Sci 2008; 53:856-860.

59 Eisenberg E, Carr DB, Chalmers TC. Neurolytic celiac plexus block for treatment of cancer pain: a metaanalysis. Anesth Analg 1995; 80:290-295.

60 Vranken JH, Zuurmond WW, Van Kemenade FJ, Dzoljic M. Neurohistopathologic findings after a neurolytic celiac plexus block with alcohol in patients with pancreatic cancer pain. Acta Anaesthesiol Scand 2002; 46:827-830

61 Mercadante S, Catala E, Arcuri E, Casuccio A. Celiac plexus block for pancreatic cancer pain: factors influencing pain, symptoms and quality of life. J Pain Symptom Manage 2003; 26:1140-1170.

62 Rykowski JJ, Hilgier M. Efficacy of neurolytic celiac plexus block in varying locations of pancreatic cancer: influence on pain relief. Anesthesiology 2000; 92:347354

63 McGreevy K, Hurley RW, Erdek MA, Aner MM, Li $\mathrm{S}$, Cohen SP. The effectiveness of repeat celiac plexus neurolysis for pancreatic cancer: a pilot study. Pain Pract 2013; 13:89-95.

64 De Cicco M, Matovic M, Bortolussi R, Coran F, Fantin D, Fabiani F, Caserta M, Santantonio C, Fracasso A. Celiac plexus block: injectate spread and pain relief in patients with regional anatomic distortions. Anesthesiology 2001; 94:561-565.

65 Erdek MA, Halpert DE, González Fernández M, Cohen SP. Assessment of celiac plexus block and neurolysis outcomes and technique in the management of refractory visceral cancer pain. Pain Med 2010; 11:92-100

66 Yan BM, Myers RP. Neurolytic celiac plexus block for pain control in unresectable pancreatic cancer. $\mathrm{Am} \mathrm{J}$ Gastroenterol 2007; 102:430-438.

67 Moore JC, Adler DG. Celiac plexus neurolysis for pain relief in pancreatic cancer. J Support Oncol 2009; 7:83-87,90.

68 Arcidiacono PG, Calori G, Carrara S, McNicol ED, Testoni PA. Celiac plexus block for pancreatic cancer pain in adults. Cochrane Database Syst Rev 2011; 16:CD007519.

69 Nagels W, Pease N, Bekkering G, Cools F, Dobbels P. Celiac plexus neurolysis for abdominal cancer pain: a systematic review. Pain Med 2013; 14:1140-1163.

70 Zhong W, Yu Z, Zeng JX, Lin Y, Yu T, Min XH, Yuan $\mathrm{YH}$, Chen QK. Celiac plexus block for treatment of pain associated with pancreatic cancer: a metaanalysis. Pain Pract 2014; 14:43-51.

71 Özyalçin NS, Talu GK, Camlica H, Erdine S. Efficacy of coeliac plexus and splanchnic nerve blockades in body and tail located pancreatic cancer pain. Eur $J$ Pain 2004; 8:539-545.

72 Wilson IB, Cleary PD. Linking clinical variables with health-related quality of life. A conceptual model of patient outcomes. JAMA 1995; 273:59-65.

73 Syrjala KL, Jensen MP, Mendoza ME, Yi JC, Fisher HM, Keefe FJ. Psychological and behavioral approaches to cancer pain management. J Clin Oncol 2014; 32:1703-1711.

74 Staats PS, Hekmat H, Sauter P, Lillemoe K. The effects of alcohol celiac plexus block, pain, and mood on longevity in patients with unresectable pancreatic cancer: a double-blind, randomized, placebocontrolled study. Pain Med 2001; 2:28-34.

75 Saloman JL, Albers KM, Li D, Hartman DJ, Crawford HC, Muha EA, Rhim AD, Davis BM. Ablation of sensory neurons in a genetic model of pancreatic ductal adenocarcinoma slows initiation and progression of cancer. Proc Natl Acad Sci USA 2016; 113:3078-3083.

76 Saloman JL, Albers KM, Rhim AD, Davis BM. Can 
stopping nerves, stop cancer? Trends Neurosci 2016; 39:880-889.

77 Goroszeniuk T, di Vadi P. Use of contrast before percutaneous neurolytic block. Reg Anesth Pain Med 2000; 25:437-438.

78 Busch EH, Kay D, Branting SB. Low volume neurolytic celiac plexus block with computed tomography guidance. Anesthesiology 2003; 99:12431244.

79 Dolly A, Singh S, Prakash R, Bogra J, Malik A, Singh V. Comparative evaluation of different volumes of $70 \%$ alcohol in celiac plexus block for upper abdominal malignsancies. South Asian J Cancer 2016; 5:204-209.

80 Patt RB, Cousins MJ. Neurolytic blockade techniques for chronic and cancer pain. In: Cousins MJ, ed. Neural Blockade in Clinical Anesthesia and Management of Pain. 3rd ed. Philadelphia: Lippincott Williams \& Wilkins, 1998:1007-1061.

81 Ramamurthy S, Walsh NE, Schoenfeld LS, et al. Evaluation of neurolytic blocks using phenol and cryogenic block in management of chronic pain. J Pain Symptom Manage 1989;4:72-75.

82 Burton AW, Phan pc, Cousins MJ. Treatment of cancer pain: Role of neural blockade and neuromodulation. In: Neural Blockade in Clinical Anesthesia and Pain Medicine. Lippincott Wiliams and Wilkins, Philadelphia, 2009, pp 1111-1153.

83 Molloy R, Benzon H. Neurolytic blocking agents: Uses and complications. In: Raj's Practical Management of Pain. Mosby Elsevier, Philadelphia, PA, 2008, pp 839-850.

84 Sunderland S. Nerves and nerve injuries. Livingstone, Edinburgh \& London 1968, p 180

85 Lipton S. Neurolysis: pharmacology and drug selection. In: Patt RB, ed. Cancer Pain. Philadelphia: Lippincott, 1993:343-358.

86 Koyyalagunta D, Engle MP, Yu J, Feng L, Novy DM The effectiveness of alcohol versus phenol based splanchnic nerve neurolysis for the treatment of intra-abdominal cancer pain. Pain Physician 2016; 19:281-292.

87 Davies DD. Incidence of major complications of neurolytic coeliac plexus block. J R Soc Med 1993; 86:264-266.

88 Black A, Dwyer B. Coeliac plexus block. Anaesth Intensive Care 1973; 1:315-318.

89 Lieberman RP, Waldman SD. Celiac plexus neurolysis with the modified transaortic approach. Radiology 1990; 175:274-276.

90 Kaplan R, Schiffkeren B, Alt E. Aortic dissection as a complication of cleiac plexus block. Anesthesiology $1995 ; 83: 632-635$.

91 Fine PG, Bubela C. Chylothorax following celiac plexus block. Anesthesiology 1985; 63:454-456.

92 Rosenthal JA. Diaphragmatic paralysis complicating alcohol splanchnic nerve block. Anesth Analg 1998; 86:845-846.

93 Pello S, Miller A, Ku T, Wang D. Hemorrhagic gastritis and duodenitis following celiac plexus neurolysis. Pain Physician 2009; 12:1001-1003. 